\title{
Retrograde Transport of Goldfish Optic Nerve Proteins Labeled by N-Succinimidyl [ $\left.{ }^{3} \mathrm{H}\right]$ Propionate
}

\author{
LAWRENCE R. WILLIAMS* and BERNARD W. AGRANOFF** \\ Neuroscience Laboratory and Mental Health Research Institute, The University of Michigan, Ann Arbor, MI 48109 (U.S.A.)
}

(Accepted July 6th, 1982)

Key words: retrograde transport $-\mathrm{N}$-succinimidyl $\left[{ }^{3} \mathrm{H}\right]$ propionate - retinal ganglion cell - optic nerve

\begin{abstract}
Following injection of the acylating reagent $\mathrm{N}$-succinimidyl $\left[{ }^{3} \mathrm{H}\right]$ propionate into the optic nerve of goldfish, labeled protein appeared in the ipsilateral retina and contralateral tectum in a time-dependent manner. Autoradiography indicated the presence of the labeled material in the neuroplasm of the retinal ganglion cells and their projections. While most of the recoverable injected radioactivity was confined to the injection site even after 1 week, labeled proteins arriving in the retina by retrograde flow or in the tectum by anterograde flow had distinctly different patterns, a result suggesting specific transport processes rather than diffusion. In contrast to reported studies with the labeling agent in other species, a prominent 68,000 molecular weight component was not seen. The results are discussed in relation to the role of retrograde transport in regeneration.
\end{abstract}

\section{INTRODUCTION}

Following crush of the optic nerve in the goldfish, a sequence of biochemical events unfold in the retina that may be causally related to regeneration of the severed ganglion cell axon $7,17,18,23$. The nature of the signal to the ganglion cell that its axon has been injured, and which leads to the initiation, maintenance, and termination of these alterations, is unknown. Biochemical explanations include the possible loss of a regulatory suppressor substance normally transported retrogradely from the synapse, or alternatively the retrograde transport of an activating substance produced at the injury site $2,8,10$. In either case, retrograde axonal flow is implicated. While there are indications that endogenous proteins can migrate retrogradely $3,37,40$ most reports of retrograde flow rates deal with exogenously added markers ${ }^{25}$ and hence shed little light on the nature of putative retrogradely transported substances that could initiate or sustain the regenerative response.

Fink and Gainer ${ }^{11,12}$ recently introduced the use of an acylating agent, $\mathrm{N}$-succinimidyl $\left[{ }^{3} \mathrm{H}\right]$ propionate $\left(\left[{ }^{3} \mathrm{H}\right] \mathrm{NSP}\right)$, to label proteins in the intact sciatic nerve of the rat. A fraction of the applied agent is believed to permeate the axolemma intact and covalently react with intra-axonal free amino groups so that subsequent anterograde or retrograde movement of the labeled proteins can then be measured. We report here the use of $\left[{ }^{3} \mathrm{H}\right] \mathrm{NSP}$ to label proteins in the optic nerve of the goldfish with particular reference to the possible presence of retrogradely transported proteins.

\section{MATERIALS AND METHODS}

\section{$N$-succinimidyl $\left[{ }^{3} \mathrm{H}\right]$ propionate injections}

$\left[{ }^{3} \mathrm{H}\right]$ NSP was obtained from Amersham Corporation (Arlington Heights, $\mathrm{IL}$ ) in toluene solution (50 $\mathrm{Ci} / \mathrm{mmol} ; 1 \mathrm{mCi} / \mathrm{ml})$. This acylating agent reacts rapidly with amino groups at physiological $\mathrm{pH}$ and hydrolyzes slowly in aqueous solutions ${ }^{6}$. To minimize hydrolysis, the $\left[{ }^{3} \mathrm{H}\right] \mathrm{NSP}$ was prepared according to Fink and Gainer ${ }^{11}$. About $1 \mathrm{ml}$ of the toluene

\footnotetext{
* Present address: Department of Biology, University of California at San Diego, M-001, La Jolla, CA 92093, U.S.A.

** To whom correspondence should be sent.
} 
solution was evaporated to about $50 \mu \mathrm{l}$ in a $2 \mathrm{ml}$, siliconized, Microflex vial (Kontes, Vineland, $\mathrm{NJ}$ ) at $37^{\circ} \mathrm{C}$ under a stream of dry nitrogen. The concentrate was then transferred to a $200 \mu 1$ Microflex vial containing $10 \mu \mathrm{l}$ of saline and evaporation continued until only the aqueous phase remained. The vial was vortexed, centrifuged and kept at $4{ }^{\circ} \mathrm{C}$ until injection. This preparation provided sufficient material to inject each of 6 fish with $50-100 \mu \mathrm{Ci}$ of active reagent in $1 \mu \mathrm{l}$. Reactive of the $\left[{ }^{3} \mathrm{H}\right] \mathrm{NSP}$ was monitored both before and after the fish injections by reacting $0.12 \mu \mathrm{l}$ of the saline preparation with 0.5 $\mathrm{ml}$ of $1 \%$ BSA. Protein-bound radioactivity was determined after precipitation with TCA and pellet solubilization in Soluene 350 (Amersham, Arlington Heights, IL). The $t \frac{1}{2}$ of labeled NSP hydrolysis in saline at $4{ }^{\circ} \mathrm{C}$ was $2.8 \mathrm{~h}$.

Goldfish (Carassius auratus), $12-16 \mathrm{~cm}$ in body length, weighing 30-35 g (Ozark Fisheries, Stoutland, MO or Grassy Forks Fisheries, Martinsville, IN) were prepared for isotope injection after anesthetization in tricaine methanesulfonate (Finquel, Ayerst Laboratories, New York, NY). Under a dissecting microscope, the right optic nerve was exposed by cutting the dorsal conjunctiva and aspirating intraorbital fat. The eye was displaced ventrally by inserting a 27 -gauge needle from a dorsotemporal direction under the exposed optic nerve into the nasal wall of the orbit. A small dorsotemporal bone flap was reflected to improve visibility. If major blood vessels, including the central artery of the retina, were damaged during this preparation, the fish was not used.

A 32-gauge needle, no. 2 point (Hamilton, Monroeville, PA) was used for $\left[{ }^{3} \mathrm{H}\right]$ NSP injection. The needle was modified by cutting and hand grinding the original bevel to an angle of about $45^{\circ}$ such that the length of the bevel was less than $0.5 \mathrm{~mm}$. The needle was mounted on a micromanipulator inside a $50 \mu \mathrm{l}$ pipette tube and was sealed with methacrylate to PE10 tubing which in turn was fitted over the fixed needle of a Hamilton syringe. The line was filled with water and a small air bubble was introduced prior to introduction of the $\left[{ }^{3} \mathrm{H}\right] \mathrm{NSP}$ solution. The needle penetrated the right optic nerve within a $\mathrm{mm}$ of its exit from the orbit, i.e. $4-5 \mathrm{~mm}$ distal to the eyeball and $<1 \mathrm{~mm}$ from the optic chiasm. The $\left[{ }^{3} \mathrm{H}\right] \mathrm{NSP}$ solution was injected in a $1 \mu \mathrm{l}$ volume over 8 min using a compact infusion pump (Harvard Apparatus, Dover, MA). The orbit was aspirated during the injection. Following completion of the injection, the bone flap was replaced, and after $10 \mathrm{~min}$, the fish was returned to a 10 gallon circulating aquarium maintained at $20-22$ C.

\section{Analysis of TCA-insoluble radioactivity}

Fish were dark-adapted and sacrificed by spinal cord transection $2 \mathrm{~h}, 1,3$ or 7 days post-injection (PI). Right and left retinas were then removed ${ }^{18}$. Fish were chilled to $4{ }^{\circ} \mathrm{C}$ and left and right tectum and right optic nerve and tract were then dissected, removed and freed of adherent material, and stored at $-70{ }^{\circ} \mathrm{C}$. They were thawed and homogenized in $0.3 \mathrm{ml}$ of $62.5 \mathrm{mM}$ Tris- $\mathrm{HCl}$ buffer ( $\mathrm{pH} 6.8$ ), and TCA-insoluble radioactivity was determined by a filter paper method 27 . Protein was solubilized by heating the filter papers in $1 \mathrm{ml}$ of Soluene 350 for 2 $\mathrm{h}$ at $60^{\circ} \mathrm{C}$. Samples were counted in a scintillation counter after the addition of $10 \mathrm{ml}$ of ACS (Amersham) and $100 \mu \mathrm{l}$ of glacial acetic acid (counting efficiency, $29 \%$ ). Statistical significance was established with the paired Student's $t$-test.

\section{Autoradiography}

At 1, 3 or 7 days PI, goldfish were dark-adapted and anesthetized with tricaine methanesulfonate. Hemisected eyes were immersed with the whole brain in $2 \%$ glutaraldehyde and $2 \%$ paraformaldehyde in $0.15 \mathrm{M}$ sodium cacodylate buffer, $\mathrm{pH} 7.4$. The following day, the tissues were rinsed thoroughly, frozen, and $10 \mu \mathrm{M}$ cryostat sections were mounted on subbed slides, which were then dipped in Kodak NTB-2 emulsion. After 1 or 2 week exposures at $4{ }^{\circ} \mathrm{C}$, the autoradiograms were developed and stained in $0.1 \%$ cresyl violet.

\section{Polyacrylamide gel electrophoresis (PAGE)}

Pools of two retinas or right optic nerves were homogenized in $0.3 \mathrm{ml}$ of $62.5 \mathrm{mM}$ Tris- $\mathrm{HCl}$ buffer (pH 6.8) containing $6 \mathrm{M}$ urea, $1 \%$ sodium dodecyl sulfate (SDS) and 5\% 2-mercaptoethanol ${ }^{20}$. The homogenates were heated $5 \mathrm{~min}$ in a boiling water bath, rehomogenized, and centrifuged at $100,000 \mathrm{~g}$ for $2 \mathrm{~h}$ at $22{ }^{\circ} \mathrm{C}$. Portions of the supernatant $(90-100$ $\mu 1)$ were electrophoresed on $10 \%$ acrylamide slab gels ${ }^{24}$. 
Labeled proteins present in the retina, tectum and optic nerve were detected by dividing the polyacrylamide gels (approximately $120 \mathrm{~mm}$ long) into 1.1 $\mathrm{mm}$ slices. The slices were either pooled as $2 \mathrm{ad}-$ jacent pieces or counted individually, depending on the amount of radioactivity applied to the gel. The acrylamide was solubilized by a $48 \mathrm{~h}$ incubation at $60{ }^{\circ} \mathrm{C}$ in $0.4 \mathrm{ml} 30 \% \mathrm{H}_{2} \mathrm{O}_{2}$. Radioactivity was determined after addition of $4 \mathrm{ml}$ of ACS. Labeled proteins present in the optic nerve were also identified by fluorography 5 .

Apparent molecular weights were estimated using the assumptions of Weber and Osborn ${ }^{39}$. The following protein standards were used (Sigma, St. Louis, MO): lysozyme $(14.3 \mathrm{~K}), \beta$-lactoglobulin (18.4 K), trypsinogen ( $24 \mathrm{~K})$, ovalbumin ( $45 \mathrm{~K})$, and bovine serum albumin $(66 \mathrm{~K})$. The radioactivity in labeled protein bands was expressed as percent of total recovered radioactivity. Statistical differences were determined using the unpaired Student's $t$-test.

\section{RESULTS}

\section{Analysis of TCA-insoluble protein}

The amount of TCA-insoluble radioactivity recovered from the retinas, tecta and right optic nerve varied widely between fish, presumably a reflection of the efficacy of the isotope injection as well as the variability in $\left[{ }^{3} \mathrm{H}\right] \mathrm{NSP}$ reactivity with tissue proteins. During the time span of injecting 6 fish (approximately $2 \mathrm{~h}$ ), $40 \%$ of the freshly prepared aqueous solution of the reagent was hydrolyzed. The injection volume in the various experiments contained $30-100 \mu \mathrm{Ci}$ of active $\left[{ }^{3} \mathrm{H}\right] \mathrm{NSP}$. At $2 \mathrm{~h} \mathrm{PI}$, only $52.2 \pm 0.6 \%$ (S.E.M.) of the total radioactivity present in the optic nerve was TCA-insoluble. At 1 day PI and 7 days PI, $78.3 \pm 2 \%$ and $90.6 \pm 4 \%$ of the radioactivity was TCA-insoluble, respectively. While its nature was not pursued, the TCA-soluble radioactivity presumably consisted of propionate metabolites and condensation products of $\left[{ }^{3} \mathrm{H}\right] \mathrm{NSP}$ with soluble amines. By 1 day PI most of the hydrolyzed $\left[{ }^{3} \mathrm{H}\right] \mathrm{NSP}$ was apparently cleared from the animals. The aquarium water accounted for about $50 \%$ of the radioactivity injected. Only $3-6 \%$ of the total active $\left[{ }^{3} \mathrm{H}\right] \mathrm{NSP}$ injected was recovered as TCA-insoluble radioactivity in the combined values for the tissues sampled and of this $>95 \%$ was localized in the region of the injection site. At 1 day PI, the TCA-insoluble radioactivity in the retinas accounted for $5.1 \pm 1.1 \%$ of the total. Even at 7 days PI, despite the apparent clearing of considerable TCA-soluble radioactivity, TCA-insoluble radioactivity was only $25 \pm 0.8 \%$ of the total recovered in retina. Blood and extracellular fluid presumably contain labeled TCA-soluble molecules with a slow turnover, including $\left[{ }^{3} \mathrm{H}^{3} \mathrm{H}_{2} \mathrm{O}\right.$.

Because of the variability of injected and recovered radioactivity, the most useful way to compare the accumulation of radioactivity in the retinas and tecta was as a fraction of total recovered TCAinsoluble radioactivity from the combined values for right optic nerve, right and left retinas, and right and left tecta per pooled pair of fish (Fig. 1). Since the visual tracts of the goldfish are essentially $100 \%$ crossed, the left retina and right tectum serve as internal control tissues. The radioactivity in right and left retinas became significantly different by 3 days PI. By 7 days PI the percent TCA-insoluble radioactivity in the right retina was 3.7-fold greater than at $2 \mathrm{~h}$ PI and 4.8-fold greater than the 7-day PI left retina. Accumulation of radioactivity in the left

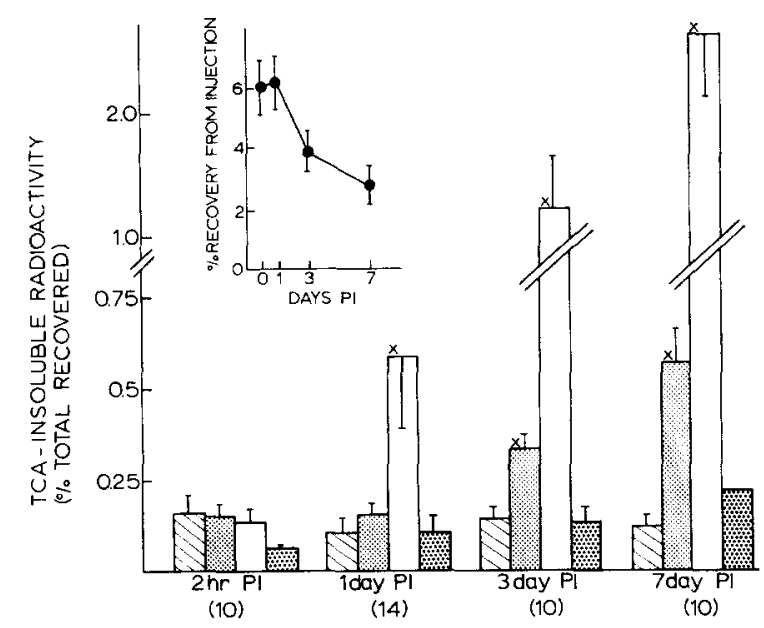

Fig. 1. Accumulation of TCA-insoluble radioactivity in retina and tectum after injection of $\left[{ }^{3} \mathrm{H}\right] \mathrm{NSP}$. Labeling of the retina is expressed as percent of total radioactivity recovered from the combined values for right optic nerve, and left and right retina and tectum \pm S.E.M. The number of samples per time period is in parentheses. ${ }^{*} P \leq 0.02$; striped columns, left retina; finely shaded columns, right retina; open columns, left tectum; coarsely shaded columns, right tectum. Inset, the amount of TCA-insoluble radioactivity recovered from the visual tissues as a percentage of the total active reagent injected \pm S.E.M. PI, post-injection. 0 day PI represents the $2 \mathrm{~h}$ PI labeling pulse. 


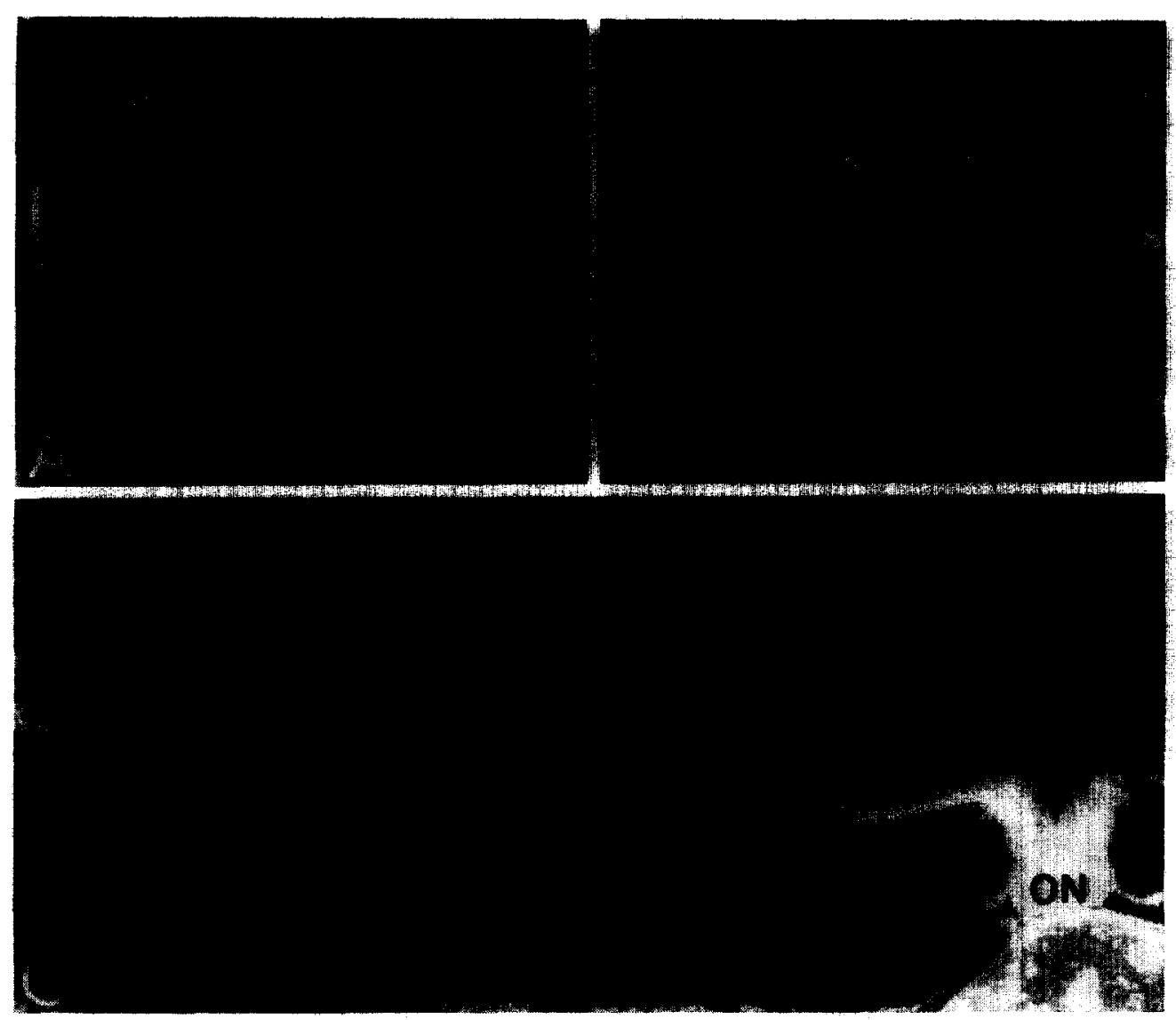

Fig. 2. A : dark-field of whole brain coronal section, 1 day PI, viewed postero-anterior. The left tectum is heavily labeled with silver grains. The right tectum is not labeled. Square enclosure is enlarged in B. Bar $=1 \mathrm{~mm}$. B: dark-field microscopy of enclosure from A. SM, stratum marginale; SO, stratum opticum ; SFGS, stratum fibrosum et griseum superficialis; $S G C$, stratum griseum centrale $\mathrm{Bar}=100 \mu \mathrm{m}$. Silver grains are localized in the layers of retinal ganglion cell axons and terminals. $C$ : dark-field of right retina (R), 1 day PI. The retina was dark-adapted and is separated at the pigmented epithelium (PE) which appears white. Under dark-field illumination, silver grains also appear white and are seen in the optic nerve (ON) at the macula and in the ganglion cell layer (GCL). No specific labeling of retinal layers was observed in the left retina. Bar $\cdots 1 \mathrm{~mm}$.

tectum became significantly greater than that in the right by 1 day PI. By 7 days PI the left tectum had 12.5-fold more TCA-insoluble radioactivity than the control tectum.

The total TCA-insoluble radioactivity recovered was always primarily in the injected optic nerve and was observed to decrease with time when expressed as a percent of the estimated amount of active $\left[{ }^{3} \mathrm{H}\right]$ NSP injected (Fig. 1, inset). There was a loss of approximately $50 \%$ of TCA-insoluble radioactivity in the optic nerve by 7 days PI. This could account for some of the apparent percent increase calculated for the right retina and left tectum as a function of time following injection. However, even after the decrease in optic nerve radioactivity is taken into account, the 7-day PI accumulation in the right retina is 1.6-fold greater than at $2 \mathrm{~h} \mathrm{PI}$. The ratios of right to left retina at each time period, unaffected by the dimunition with time in optic nerve radioactivity, also increased with time following injection.

\section{Autoradiography}

The accumulation of radioactivity in the right retina and left tectum (Fig. 2) was due to specific localization of radiolabeled proteins in the retinal ganglion cells, their axons and terminals. Fig. $2 \mathrm{~A}$ and $\mathrm{B}$ show that radioactivity in the brain accumulated in the stratum opticum and stratum fibrosum et griseum superficiale of the left tectum, the optic fiber layer and major termination layer of the retinal ganglion cells, respectively. The distribution of radioactivity within these layers was 
similar to that described in other autoradiographic, anterograde axonal transport studies ${ }^{28,30,36}$. No difference was apparent between the localization of radioactivity in the left tectum at 1 day PI (Fig. 2A), 3 days PI or 7 days PI (not shown). Figs. $2 \mathrm{C}$ and 3 demonstrate that the radioactivity in the right retina was localized within axons of the optic fiber layer and accumulated in ganglion cells and the inner plexiform layer, presumably representing the accumulation of labeled protein within ganglion cell
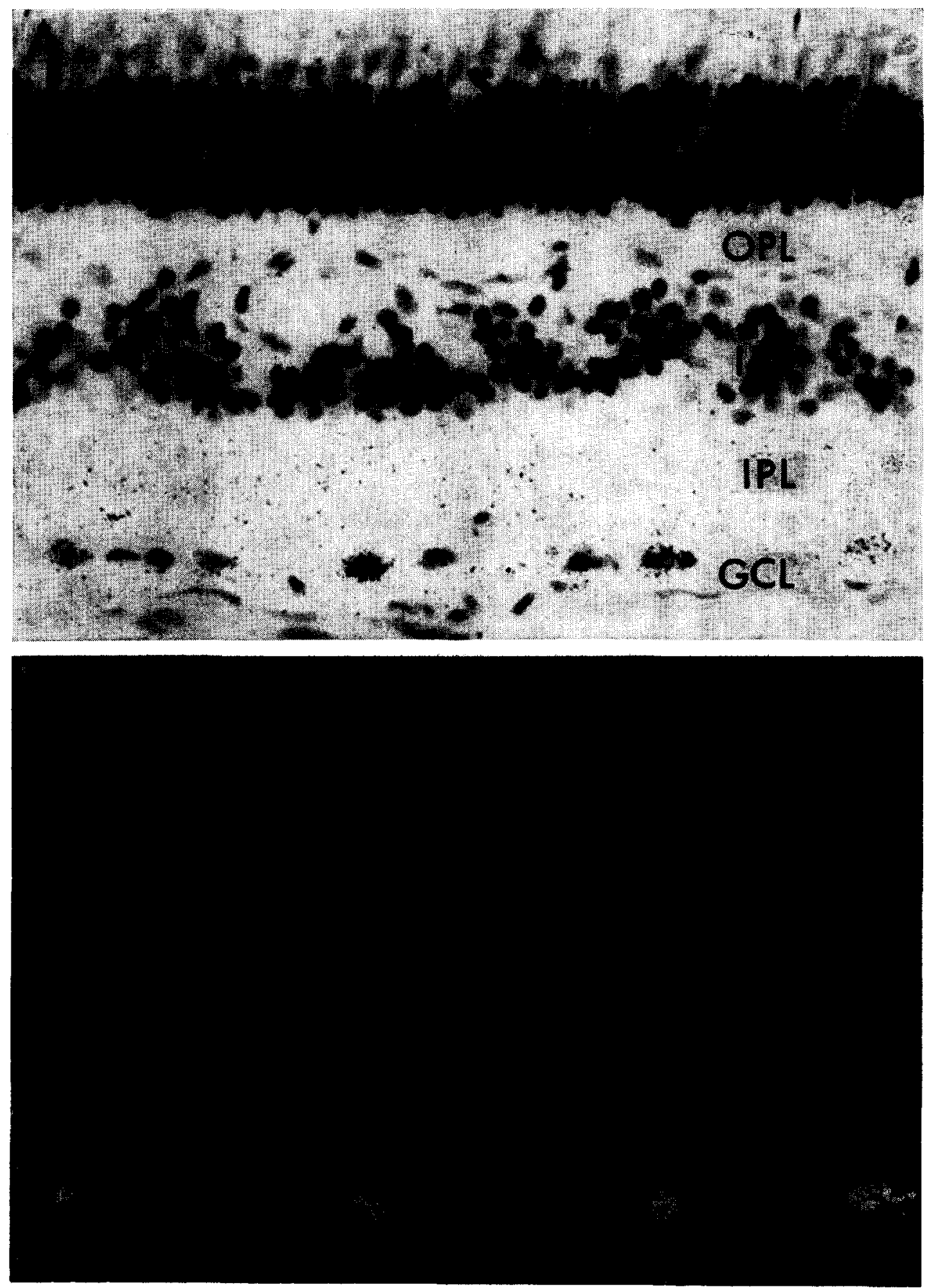

Fig. 3. A : light-field, and B: dark-field microscopy of right retina 3 days PI. ONL, outer nuclear layer; OPL, outer plexiform layer; INL, inner nuclear layer; IPL, inner plexiform layer; GCL, ganglion cell layer. Silver grains have accumulated over ganglion cells and the inner plexiform layer. Specific labeling did not occur in the left retina. Bar $=10 \mu \mathrm{m}$. 


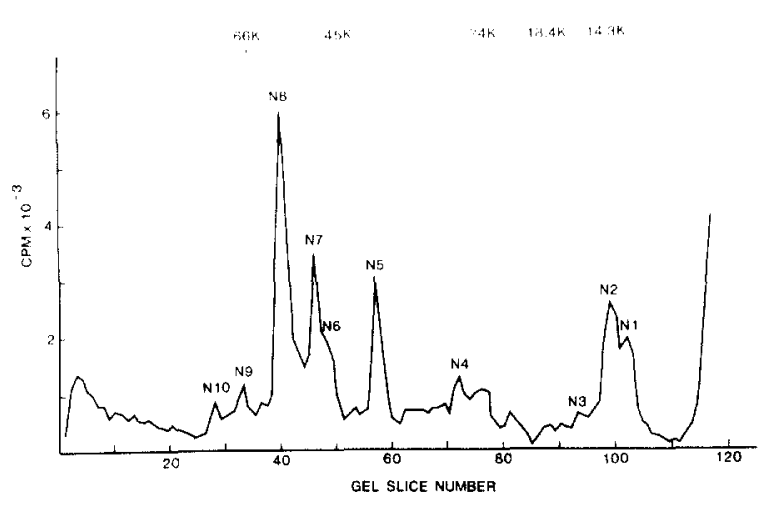

dendrites. A selective deposition of silver grains was not observed over the cell layers of the left retina. Similar radioactivity patterns were observed at 1 day PI (Fig. 2C), 3 days PI (Fig. 3) and 7 days PI. The tissue sections had been thoroughly rinsed so that autoradiographic patterns reflect primarily insoluble radioactivity. In both tecta and in retinas, there was

Fig. 4. Radioactive protein profiles of the right optic nerve $2 \mathrm{~h}$ PI. Apparent molecular weights of the bands $\left(\times 10^{-3}\right)$ are (n $=6): \mathrm{N} 1,13.6 ; \mathrm{N} 2,14.5 ; \mathrm{N} 3,16 ; \mathrm{N} 4,27 ; \mathrm{N} 5,37 ; \mathrm{N} 6,47$; N7, 49; N8, 57; N9, 70; N10, 79.

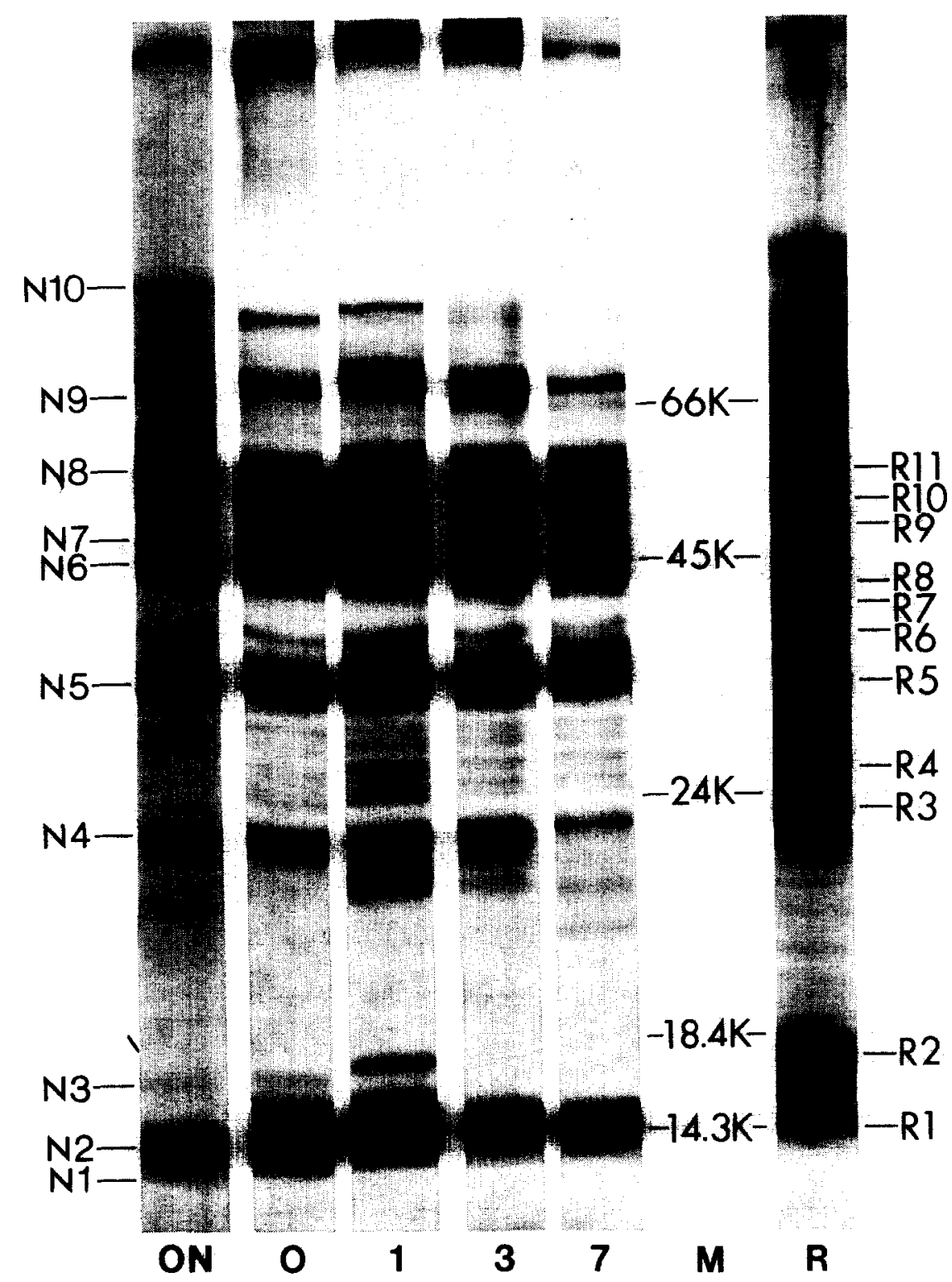

Fig. 5. Coomassie blue stain and fluorographs of PAGE gels of optic nerve (ON), retina (R), and molecular weight standards (M) at 2 h PI (0), 1 day PI (1), 3 days PI (3) and 1 week PI (7). For each fluorogram, 200,000 cpm of TCA-precipitable material was applied to the gel. Apparent molecular weights $\left(\times 10^{-3}\right)$ are as in Fig. 4. Apparent molecular weights $\left(1^{-3}\right)$ of the major retinal proteins are $(\mathbf{n}=5): \mathbf{R} 1,14 ; \mathrm{R} 2,17 ; \mathbf{R} 3,27 ; \mathbf{R} 4,30 ; \mathrm{R} 5,35 ; \mathrm{R} 6,39 ; \mathbf{R} 7,41 ; \mathrm{R} 8,43 ; \mathrm{R} 9,49 ; \mathrm{R} 10,51 ; \mathrm{R} 11,54$. 
evidence of low levels of radioactivity present in blood vessels, indicating that blood-borne, radiolabeled proteins were present in these tissues.

\section{Analysis of labeled proteins at the injection site}

Profiles of labeled proteins present in the optic nerve $2 \mathrm{~h}$ PI (0 day) are shown in Fig. 4. The calculated $\mathrm{M}_{\mathbf{r}}$ of the major band (N8) corresponds to $57 \mathrm{~K}$. The 10 peaks identified by counting slices in Fig. 4 and by fluorography in Fig. 5 generally correspond to bands seen on Coomassie blue staining (Fig. 5). Comparison of fluorography profiles for days $0,1,3$ and 7 shown in Fig. 5, consistently showed a decrease in intensity with time of the bands at $\mathrm{N} 10$ and in the N2-N3 region.

\section{Analysis of labeled proteins in the retina}

The low levels of radioactivity in the retinas necessitated the counting of gel slices in pairs, i.e. in $2.2 \mathrm{~mm}$ sections (Fig. 6). Significant left-right differences in PAGE profiles of retinal proteins were seen only after $24 \mathrm{~h}$ PI. Labeled proteins in the right retina at $24 \mathrm{~h}$ differed in apparent molecular weight and predominance from the retinal Coomassie blue staining pattern (Fig. 5). While there was considerable variability in the labeling pattern of right retina $24 \mathrm{~h}$ PI, the most consistent and prominent band (1RT2: $16 \%$ of total recovered radioactivity in the retina) had an apparent molecular weight of $32 \mathrm{~K}$. The arrival of this band and others shown in Fig. 6 corresponds to a retrograde transport rate of at least

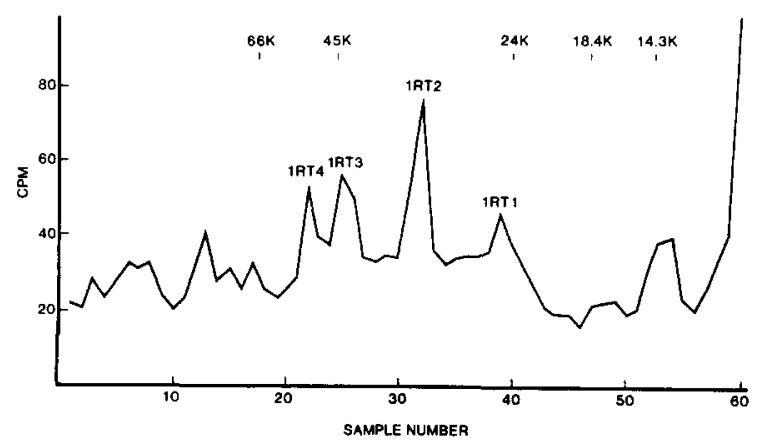

Fig. 6. Profile of labeled proteins from 1 day PI right retina. Samples were counted as $2.2 \mathrm{~mm}$ gel slices. The apparent molecular weights $\left(\times 10^{-3}\right)$ and $\%$ total recovered retinal radioactivity for the retrogradely transported (RT) proteins were $(\mathrm{n}=7): 1 \mathrm{RT} 1,25,11 \% ; 1 \mathrm{RT} 2,32,16 \% ; 1 \mathrm{RT} 3,43$, $13 \% ; 1 \mathrm{RT} 4,51,10 \%$; 1 RT5, $65,12 \%$.

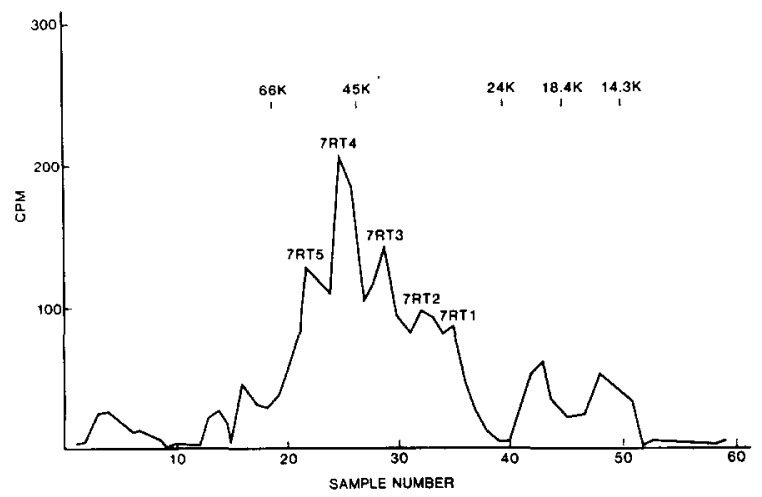

Fig. 7. Profile of labeled proteins from 7 day PI right retinas. PAGE gels were sliced at $2.2 \mathrm{~mm}$, solubilized, and counted. The apparent molecular weights $\left(\times 10^{-3}\right)$ and percent total recovered radioactivity for the retrogradely transported (RT) proteins are $(\mathrm{n}=5): 7 \mathrm{RT} 1,27,6 \% ; 7 \mathrm{RT} 2,33,8 \% ; 7 \mathrm{RT} 3,37$. $12 \%$; 7RT4, 46, 19\%; 7RT5, 54, $15 \%$.

$4 \mathrm{~mm}$ per day. At 7 days PI, 5 bands were consistently detected in the labeled right retina (Fig. 7), and their arrival corresponds to a minimal transport rate of $0.6 \mathrm{~mm} /$ day. The 7-day PI retrogradely transported proteins appear different from those seen 1 day PI (Fig. 6). The left retinas at 1 day and 7 days $P I$ contained insufficient radioactivity for resolution of labeled protein by PAGE.

\section{Analysis of labeled proteins in the left tectum}

The profiles of labeled proteins observed in the left tectum at 1 day PI and 7 days PI are shown in Fig. 8. Major peaks are similar at both 1 day and 7 days PI. While there is a 4 -fold increase in radioactivity with time, the distribution pattern at the two times are similar and distinct from that seen in either the retina or optic nerve.

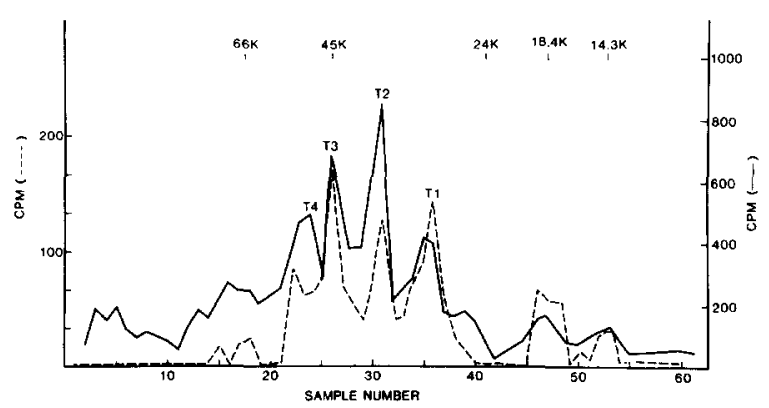

Fig. 8. Profile of labeled proteins from a left tectum at 1 day PI (broken line) and of one at 7 days PI (unbroken line). Both graphs were obtained from $2.2 \mathrm{~mm}$ gel slice counts. 


\section{DISCUSSION}

How a neuron recognizes that its axon has been injured and whether or not the cell will die or regenerate are interrelated questions, since the nature of the signal from the site of injury may in fact determine which kind of response will be elicited in the perikaryon. The goldfish visual system has proven to be a useful model for the study of regeneration, partly because of its accessibility to experimental procedures, and also because it furnishes a model of CNS regeneration, generally not seen in warm-blooded vertebrates. In vitro labeling studies with goldfish retinas have shown, for example, that 3-5 days following optic nerve crush, enzymes of uridine metabolism are selectively increased in the injured retina ${ }^{23}$ and retinal tubulin synthesis is stimulated ${ }^{18}$. In vivo alterations are seen in anterogradely transported proteins following injection of labeled amino acids into the eye. In confirmation of findings in other species ${ }^{32,33}$, growth-associated proteins are shown to be transported in the goldfish optic nerve in response to axotomy1. Tubulin might be considered to be a slowly transported growth-associated protein, since its synthesis and transport is increased about 50 -fold in the newly-regenerated optic nerve ${ }^{19}$. Two other slowly-transported components, $\mathrm{M}_{\mathrm{r}}=68-69 \mathrm{~K}$, are also associated with regeneration of the goldfish optic nerve ${ }^{19}$.

What evidence we have for retrograde flow and its rate(s) is derived from studies on uptake of exogenous proteins ${ }^{25}$, from disruption of transport by ligature or cold block $3,4,40$, and from direct microscopic measurement of rates of movement of intraaxonal particles detected by light microscopy ${ }^{13}$. These various measures, while revealing rates of retrograde transport, do not lead to information regarding the nature of the substances that are normally transported, let alone what may happen following nerve injury. A method that might be applicable for such purposes was introduced by Gainer and Fink ${ }^{11,12}$ who found that the injection of $\left[{ }^{3} \mathrm{H}\right]$ NSP into the rat sciatic nerve resulted in anterograde and retrograde transport of ${ }^{3} \mathrm{H}$-labeled protein, the latter at rates of 3-6 mm/day. Retrogradely transported proteins with rapid rates $(96 \mathrm{~mm} /$ day and $182 \mathrm{~mm} /$ day) have recently been reported following application of $\left[{ }^{3} \mathrm{H}\right] \mathrm{NSP}$ to the rat sciatic nerve ${ }^{26}$. The latter rate corresponds well with retrograde flow rates established by cold block ligature ${ }^{4}$.

In the present study we find that, as in the rat, labeling is intense at the injection site. Proteins labeled in situ should include those in the extracellular fluid, perineurial and axolemmal membranes, glia and myelin. The Coomassie blue and fluorographic bands correspond to those reported for optic nerve proteins in the teleost ${ }^{9,14,16}$.

The possibility exists that radioactivity arriving in the retina is transported anterogradely by tectal efferent pathways ${ }^{31}$. The likelihood that this quantitatively minor pathway contributes significantly is small, particularly since the autoradiographic evidence indicates that ganglion cells are selectively labeled, as anticipated from retrograde transport.

Profiles of radioactivity arriving at the retina and contralateral tectum are qualitatively different from those found at the injection site, as well as from each other, indicating that labeled proteins are indeed transported in both directions. It is evident from the autoradiographic evidence that the majority of the labeled material remains intraneuronal and appears in the ganglion cell bodies and dendrites in the retina and in their presynaptic projections to the tectum. Considerable variability due in large measure to the low levels of incorporation observed preclude definitive conclusions regarding rates of individual components. Observed differences in labeling profiles typical of various times PI are nevertheless indicative of multiple transport rates of the retrogradely transported proteins. For example, a prominent band (1RT2, Fig. 6), seen $24 \mathrm{~h}$ PI with an $\mathrm{M}_{\mathrm{r}}$ of $32 \mathrm{~K}$ is calculated to migrate at a rate of at least 4 $\mathrm{mm} /$ day. Conversely, prominent bands seen at 7 days PI (e.g. 7RT4, Fig. 7; $\mathrm{M}_{\mathrm{r}}=46 \mathrm{~K}$ ) are not apparent on day 1 .

A striking difference between the results of this study and that seen in the previous use of this agent in the rat ${ }^{11,12}$ is the absence of a prominent $68 \mathrm{~K}$ retrogradely transported band. Even allowing for a 5- to 6-fold slower anticipated transport rate in the fish than in the mammal $(70 \mathrm{~mm} /$ day for rapid anterograde transport in the fish compared with $400 /$ day in the rat), there was ample time for a $68 \mathrm{~K}$ band to have arrived at the retina.

There is considerable evidence that the labeled 68 
$\mathrm{K}$ band in the sciatic nerve is in fact labeled serum albumin $^{15}$ which is presumed to be a normal axoplasmic constituent, having entered the nerve in the region of motor terminals ${ }^{34}$. Why the small amount of plasma protein in the axoplasm should be highly labeled by $\left[{ }^{3} \mathrm{H}\right]$ NSP is unexplained. It remains possible that albumin present in the extracellular fluid near the injection site becomes highly labeled by extraneuronal $\left[{ }^{3} \mathrm{H}\right] \mathrm{NSP}$, and enters the axon locally. An albumin-like substance has been shown immunocytochemically to be present in cell bodies of mammalian nerves that project to the periphery and not in those that project centrally ${ }^{34}$. The absence of a prominent $68 \mathrm{~K}$ band in the transported proteins labeled by $\left[{ }^{3} \mathrm{H}\right] \mathrm{NSP}$ in the goldfish optic nerve may then simply reflect correspondence with the mammalian distribution. It is further doubtful that a labeled $68 \mathrm{~K}$ band would appear, since in teleosts, albumin-like protein is a minor plasma constituent ${ }^{21,29}$. SDS-PAGE of goldfish plasma (not shown) revealed the major protein to have an $\mathrm{M}_{\mathrm{r}}$ of $26 \mathrm{~K}$. If the entry of plasma proteins into nerves is necessary for their regeneration, as has been proposed ${ }^{35}$, we might indeed have expected to find them in goldfish optic nerve, as in mammalian peripheral nerve. It should be noted in this regard that studies by Szaro et al. ${ }^{38}$ in the visual system of another poikilotherm,

\section{REFERENCES}

1 Benowitz, L. I., Shashoua, V. E. and Yoon, M. G.,

1 Specific changes in rapidly transported proteins during regeneration of the goldfish optic nerve, $J$. Neurosci., 1 (1981) 300-307.

2 Bisby, M. A., Retrograde axonal transport, Advanc. Cell Neurobiol., 1 (1980) 69-117.

3 Bisby, M. A., Reversal of axonal transport: similarity of proteins transported in anterograde and retrograde directions, $J$. Neurochem., 36 (1981) 741-745.

4 Bisby, M. A. and Buchan, D. H., Velocity of labeled protein undergoing anterograde and retrograde axonal transport, Exp. Neurol., 74 (1981) 11-20.

5 Bonner, W. M. and Laskey, R. A., A film detection method for tritium-labeled proteins and nucleic acids in polyacrylamide gels, Europ. J. Biochem., 46 (1974) 83-88.

6 Boyd, H., Calder, I. C., Leach, S. J. and Milligan, B., $\mathrm{N}$-acylsuccinimides as acylating agents for proteins: synthesis, hydrolysis and aminolysis, Int. J. Peptide Protein Res., 4 (1972) 109-115.

7 Burrell, H. R., Heacock, A. M., Water, R. D. and Agranoff, B. W., Increased tubulin messenger RNA
Xenopus laevis, indicate the presence of a retrogradely transported $68 \mathrm{~K}$ protein. Since albumin-like molecules are present in even lower concentrations in amphibians than in teleosts ${ }^{29}$, the nature of the retrogradely transported protein in Xenopus should not be assumed to be directly related to that found in the rat.

The use of protein labeling reagents for the detection of possible retrogradely transported growth or injury-related proteins may require greater sensitivity than is possible with $\left[{ }^{3} \mathrm{H}\right] \mathrm{NSP}$. This might be achieved by the use of Bolton-Hunter reagent. In this reagent, used routinely for radioiodination of proteins, the $\left[{ }^{3} \mathrm{H}\right]$ propionyl moiety is replaced by the [125I]iodohydroxyphenylpropionyl group. It was recently successfully used for labeling of proteins in vivo $^{22}$ and its high specific activity suggests that it or other iodinated derivatives may prove useful in regeneration studies.

\section{ACKNOWLEDGEMENTS}

Supported by Grant NS 13743 and NIMH Training Grant (L.R.W.). The technical assistance of Judith Wye-Dvorak, Marianne Lewis and Paul Klinger is appreciated. We thank Dr. A. Heacock for useful discussions.

in the goldfish retina during optic nerve regeneration Brain Research, 168 (1979) 628-632.

8 Cragg, B. G., What is the signal for chromatolysis?, Brain Research, 23 (1970) 1-21.

9 Elam, J. S., Association of proteins undergoing slow transport with goldfish visual system myelin, Brain Research, 97 (1975) 303-315.

10 Fernandez, H. L., Singer, P. A. and Mehler, S., Retrograde axonal transport mediates the onset of regenerative changes in the hypoglossal nucleus, Neurosci. Lett., 25 (1981) 7-11.

11 Fink, D. J. and Gainer, H., Axonal transport of proteins; a new view using in vivo covalent labeling, $J$. Cell Biol., 85 (1980) 175-186.

12 Fink, D. J. and Gainer, H., Retrograde axonal transport of endogenous proteins in sciatic nerve by covalent labeling in vivo, Science, 208 (1980) 303-305.

13 Forman, D. S., Padjen, A. L. and Siggins, G. R., Effect of temperature in the rapid retrograde transport of microscopically visible intra-axonal organelles, Brain Research, 136 (1977) 215-216.

14 Franz, T., Waenheldt, T. W., Neuhoff, V. and Wachtler, K., Central nervous system myelin proteins and glycoproteins in vertebrates: a phylogenetic study, Brain $R e$ - 
search, 226 (1981) 245-258.

15 Gainer, H. and Fink, D. J., Evidence for slow retrograde transport of serum albumin in rat sciatic nerve, Brain Research, 233 (1982) 404-408.

16 Giulian, D., Ruisseaux, H. D. and Cowburn, D., A study of proteins from ganglion cells of the goldfish retina, J. biol. Chem., 255 (1980) 6486-6493.

17 Grafstein, B., The nerve cell body response to axotomy, Exp. Neurol., 48 (1975) 32-51.

18 Heacock, A. M. and Agranoff, B. W., Enhanced labeling of a retinal protein during regeneration of optic nerve in goldfish, Proc. nat. Acad. Sci. U.S.A., 73 (1976) $828-832$.

19 Heacock, A. M. and Agranoff, B. W., Protein synthesis and transport in the regenerating goldfish visual system, Neurochem. Res., 7 (1982) 771-788.

20 Hoffman, P. N. and Lasek, R. J., The slow component of axonal transport, J. Cell Biol., 66 (1975) 351-366.

21 Houston, A. H., Responses of Fish to Environmental Changes, W. Chavin (Ed.), C. C. Thomas, Springfield, IL, 1973, p. 137.

22 Katz, M. J., Lasek, R. J., Osdoby, P., Whittaker, J. R. and Caplan, A. I., Bolton-Hunter reagent as a vital stain for developing systems, Develop. Biol., 90 (1982) 419-429.

23 Kohsaka, S., Dokas, L. A. and Agranoff, B. W., Uridine metabolism in the goldfish retina during optic nerve regenera ion: cell-free preparations, $J$. Neurochem., $36(198: 1166-1174$

24 Laemm!i, U. K., Cleavage of structural proteins during the assembly of the head of bacteriophage T4, Nature (Lond.), 227 (1970) 680-685.

25 LaVail, J. H., The retrograde transport method, Fed. Proc., 34 (1975) 1618-1624.

26 McLean, W. G. and Meiri, K. F., Two rapid rates of retrograde axonal transport of protein radiolabelled with $\mathrm{N}$-succinimidyl propionate in rat sciatic nerve, J. Physiol. (Lond.), 317 (1981) 82P.

27 Mans, P. J. and Novelli, G. D., Measurement of the incorporation of radioactive amino acids into protein by a filter paper method, Arch. Biochem. Biophys., 94 (1961) 48-53.

28 Meyer, R. L., Mapping the normal and regenerating retinotectal projection of goldfish with autoradiographic methods, J. comp. Neurol., 189 (1980) 273-289.

29 Nagano, H., Hosaka, K. and Shukuya, R., Comparative biochemistry of serum albumin. A serum albuminlike protein from carp, Cyprinus carpio, Comp. Biochem. Physiol., 50B (1975) 573-578.

30 Neale, J. H., Neale, E. A. and Agranoff, B. W., Radioautography of the goldfish after intraocular injection of ${ }^{3} \mathrm{H}$-proline, Science, 176 (1972) 407-410.

31 Schmidt, J. T., The laminar organization of optic nerve fibres in the tectum of goldfish, Proc. Roy. Soc. B, 205 (1979) 287-306.

32 Skene, J. H. P. and Willard, M., Axonally transported proteins associated with axon growth in rabbit central and peripheral nervous systems, J. Cell Biol., 89 (1981) 96-103.

33 Skene, J. H. P. and Willard, M., Electrophoretic analysis of axonally transported proteins in toad retinal ganglion cells, $J$. Neurochem., 37 (1981) 79-87.

34 Sparrow, J. R., Immunocytochemical localization of plasma proteins in neuronal perikarya, Brain Research, 212 (1981) 159-163.

35 Sparrow, J. R. and Kiernan, J. A., Uptake and retrograde transport of proteins by regenerating axons, Acta Neuropathol., 47 (1979) 39-47.

36 Springer, A. D., Heacock, A. M., Schmidt, J. T. and Agranoff, B. W., Bilateral tectal innervation by regenerating optic nerve fibers in goldfish: a radioautographic, electrophysiological and behavioral study, Brain Research, 128 (1977) 417-427.

37 Stokel, K., Schwab, M. and Thoenen, H., Comparison between retrograde axonal transport of nerve growth factor and tetanus toxin in motor, sensory, and adrenergic neurons, Brain Research, 99 (1975) 1-16.

38 Szaro, B. G., Loh, Y. P. and Hunt, R. K., Use of $\left[{ }^{3} \mathrm{H}\right] \mathrm{N}-\mathrm{SP}$ to study retrograde axonal transport in Xenopus optic nerve, Biophys. J., 33 (1981) 92a.

39 Weber, K. and Osborn, M., The reliability of molecular weight determination of dodecyl sulfate-polyacrylamide gel electrophoresis, J. biol. Chem., 244 (1969) 4406-4412.

40 Whitnall, M. H., Currie, J. R. and Grafstein, B., Bidirectional axonal transport of glycoproteins in goldfish optic nerve, Exp. Neurol., 75 (1982) 191-207. 